\title{
Lijeni, glupi, temperamentni? Upotreba stereotipova o dalmatinskom mentalitetu
}

\author{
MIRA LJUBIĆ LORGER \\ Split
}

\begin{abstract}
U posljednje se vrijeme najrazličitiji događaji u Dalmaciji objašnjavaju "dalmatinskim mentalitetom". U radu se pokušava odgovoriti na pitanja o tomu što bi imao biti pojam mentaliteta, ima li ikakvu analitičku vrijednost ili pripada zastarjelom modelu promatranja društva te jesu li navodne karakteristike "dalmatinskog mentaliteta" tek predrasude i stereotipovi, a ako jesu, čemu služe - i to ponajprije čemu služe u dnevnoj politici? Također, spada li diskurs o dalmatinskom mentalitetu u tipičan (polu)orijentalistički ili čak u posebnu vrstu postkolonijalnog diskursa? Nastoji se pokazati da su razlozi oživljavanja pojma mentaliteta uglavnom izvanznanstveni, a nalaze se u suvremenom društvu, politici, ekonomiji i vladajućoj ideologiji te s namjerom njihova okamenjivanja.
\end{abstract}

Ključne riječi: mentalitet, Dalmacija, stereotipovi, ridikuli, postkolonijalizam

Za razliku od dominantnog političkog govora u Hrvatskoj u kojem je Dalmacija devedesetih godina prošlog stoljeća gotovo nestala, a zatim u drugoj deceniji dvadeset prvog ostala u jednakom položaju kao da zaista i jest nestala, u posljednje vrijeme dalmatinski mentalitet postaje sve češća "stilska figura" javnog govora. Najrazličitiji se događaji u toj regiji objašnjavaju dalmatinskim mentalitetom, govori se o humoru kao neizostavnom dijelu tog osobitog mentaliteta, o brzopletosti i naglosti, lijenosti i površnosti te o eksplozivnosti i ekstrovertiranom temperamentu kao nezaobilaznom dijelu toga sklopa.

Specifični dalmatinski mentalitet i dobar dio samih Dalmatinaca također drži bitnim dijelom svojeg identiteta. Istraživanje Damira Pilića i Suzane Kunac, objavljivano u nastavcima početkom 2003. godine, pokazalo je da svaki deseti Dalmatinac doživljava "dalmatinstvo" kroz mentalitet, odnosno temperament njezinih stanovnika (Pilić i Kunac 2003). I mimo toga, sasvim površan pogled na javno sveprisutne dojmove, tvrdnje, uvjerenja, pa i tekstove o Dalmaciji koji pretendiraju na nešto veću ozbiljnost, pokazuje da prevladavaju samoopisi u kojima se tvrdi: 
- da su Dalmatinci najduhovitiji ("narod", dio naroda, grupa) u ovom dijelu svijeta, a možda i šire;

- da je ponašanje Dalmatinaca u velikom dijelu objašnjivo njihovim legendarnim dišpetom;

- da je Split najvažniji grad na svijetu (i šire) te mu u toj "grandeci" nitko nije ravan ("ča je pusta Londra kontra Splitu gradu"), što se ne smije propitivati, a osobito ne kritizirati jer "ništa kontra Splita";

- da su pravi Splićani samo oni sa "splitskim kolinom", dok su novopridošli građani tek primitivni Vlaji i barbarski Balkanci;

- da su Dalmatinci raspjevan, uvijek dobro raspoložen, ekstrovertiran i "temperamentan" "narod" zadovoljan, eventualno, "fetom kruva", a zasigurno "žmulom vina".

Riječ je, dakako, o osobnom dojmu o javnom govoru u Dalmaciji: no tvrdnje su do te mjere dio svakodnevnice u Dalmaciji da je teško izdvojiti područje ili medij u kojem se ne nalaze.

To bi, otprilike, bilo ono pozitivno što Dalmatinci općenito i Splićani posebno misle o sebi. Vanjska je, pak, slika, kako to obično biva, manje lijepa, a u javnosti jednako, ako ne i naglašenija, i svodi se na tvrdnje da su Dalmatinci "lijeni, glupi i temperamentni", što su također sveprisutni popularni negativni stereotipovi.

Pitanja koja se u vezi s tim otvaraju su višestruka. Prije svega, što bi imao biti pojam mentaliteta, odnosno ima li on (još) ikakvu analitičku vrijednost ili posve pripada zastarjelom, nesuvremenom is dobrim razlozima odbačenom modelu promatranja društva? Nadalje, jesu li eventualne neupitne karakteristike "dalmatinskog mentaliteta" (neke ili barem njihov značajan dio) tek predrasude i stereotipovi, odnosno autostereotipovi, a ako jesu, kakve se sve zamke kriju iza njihove uporne upotrebe te čemu služe - i to ponajprije čemu služe u dnevnoj politici? Spadaju li razgovori o dalmatinskom mentalitetu u tipičan orijentalistički, odnosno poluorijentalistički, ili čak u posebnu pod/ vrstu postkolonijalnog diskursa, u ovom slučaju neuočenog i sasvim neproblematiziranog?

Pokušati odgovoriti na ta i slična pitanja, upustiti se, dakle, u raspravu o "dalmatinskom mentalitetu", pa je započeti pokušajem određenja tog sveprisutnog pojma, već se pokazuje složenijim nego što se to moglo očekivati $\mathrm{s}$ obzirom na njegovu raširenu upotrebu ne samo u svakodnevnom govoru, nego i u stručnoj literaturi. Tako se u književnopovijesnoj studiji Anatolija Kudrjavceva Vječni Split nalazi čak čitavo poglavlje nazvano "Legendarni mentalitet" s obiljem informacija o "osebujnosti lokalnog [splitskog] mentaliteta" (Kudrjavcev 1985: 333), ali ostaje zbunjenost oko toga komu ga se zapravo pripisuje, to jest pripada li čitavom promatranom društvu ili pak samo pojedinim njegovim dijelovima, odnosno podgrupama? Mijenja li se kroz povijest i kako? Kako ga razumiju u Dalmaciji, a kako izvan nje? 


\section{MENTALITET: STATUS POJMA}

Prividno, pojam mentaliteta čini se jednostavnim. Hrvatska enciklopedija navodi da je mentalitet način mišljenja, navika i reagiranja te da je riječ o općim obilježjima temperamenta ili "ćudi" nekoga naroda, etničke skupine, društvene grupe ili pojedinca. Zatim kaže da je to "prešutno prihvaćen i uglavnom naslijeđen sklop svjesnih i polusvjesnih pobuda, predodžbi, osjećaja, vrijednosti i navika svojstvenih nekoj zajednici, koji se očituje u raznorodnim oblicima ponašanja i izražavanja, od svakodnevnog ophođenja i raširenih običaja do djelâ visoke umjetnosti". ${ }^{1}$ Upućuje se na činjenicu da od početka 20. stoljeća mentalitet postaje predmet proučavanja francuske nove povijesti ili povijesti mentaliteta čiji su najpoznatiji predstavnici M. Bloch, L. Febvre, F. Braudel i J. Le Goff, pravca u historiografiji koji "povijesne događaje tumači kao rezultat kolektivnih psihičkih motivacija iščitanih iz dokumenata svakodnevnoga života zajednice u određenom razdoblju". ${ }^{2}$ Navodi se da je sociolog P. Bourdieu, za potrebe socijalne povijesti, pojam mentaliteta zamijenio habitusom, napustivši time ranije psihološko određenje mentaliteta i prevodeći ga u sustav povijesno i klasno baštinjenih spontanih obrazaca ponašanja i djelovanja koji omogućuju nekoj kulturi da oblikuje svoje predodžbe i prakse. Zanimljiv je i dio natuknice koji upućuje na razvoj, odnosno povijest samog pojma. U vezi s tim se kaže da su se u starijim naučavanjima o društvu isticale različitosti mentaliteta među rasama ili narodima i to:

najčešće radi objašnjenja ili legitimiranja postojećih nejednakosti među tim skupinama, uključujući ropstvo. U XIX. st. u psihologiji, etnologiji i historiografiji narodima se pripisivalo "mentalno jedinstvo" u smislu "duha naroda" (W. Wundt, J. G. Herder). U klasičnoj sociologiji termin "kolektivne reprezentacije" É. Durkheima i "klasna svijest" K. Marxa, premda s drugim namjerama, također izražavaju ideju o mentalnom jedinstvu. U antropologiji je bilo utjecajno shvaćanje o "primitivnome mentalitetu" kao izrazu nelogičnosti i emocionalnosti pripadnika tzv. primitivnih zajednica, za razliku od ljudi moderne civilizacije (L. Lévy-Bruhl). Danas se razlike u mentalitetu objašnjavaju s obzirom na stupanj ekonomske i političke razvijenosti ili demokracije (R. F. Inglehart) ili pak s obzirom na dugotrajne obrasce ponašanja u društvu, npr. u smislu individualizma ili kolektivizma. Razlike u mentalitetu ne podudaraju se nužno s razlikama među pojedinim narodima, rasama ili vjerskim zajednicama, budući da i unutar tih skupina postoje značajne razlike u mentalitetu. (Geert Hofstede) $^{3}$

\footnotetext{
${ }^{1} \mathrm{http} / / /$ www.enciklopedija.hr/natuknica.aspx?id=40151.

${ }^{2} \mathrm{http}: / /$ www.enciklopedija.hr/natuknica.aspx?id=40151.

${ }^{3} \mathrm{http}: / /$ www.enciklopedija.hr/natuknica.aspx?id=40151.
} 
Kako bilo, Enciklopedija, uz sve ograde koje se odnose na promjene u njegovu razumijevanju - u vremenu i u različitim znanostima - ipak ne dovodi u pitanje upotrebu pojma mentalitet. Nama je, za ovu priliku, kada nas istodobno zanimaju i diskurs o dalmatinskom mentalitetu i analiza dalmatinskih realija (u čemu, dakle, najkorisnijom metodom držimo pristup Marije Todorove koja kombinira prikaz balkanizma kao diskurzivne tvorevine s "ontologijom

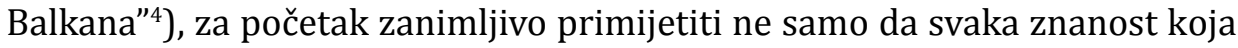
se bavi promatranjem društva ima svoju, implicitnu ili eksplicitnu, definiciju mentaliteta i da se te definicije međusobno razlikuju, nego i to da se taj pojam u jednoj znanosti, a kroz određeno vremensko razdoblje, pojavljuje i ozbiljno analizira pa onda čak posve nestaje, da bi se istodobno s tim nestajanjem u jednoj, pojavio i doživio veliki uzlet u drugoj društvenoj znanosti. S obzirom na širenje upotrebe "mentaliteta" i razorne posljedice koje je već uspio izazvati, za ozbiljnu analizu pojma bio bi potreban napor tima stručnjaka. Za sada, moramo se ograničiti na tek nekoliko primjera koji će uputiti na to da je pojam ipak znatno kompleksniji nego se čini čitanjem natuknice koju smo opširno naveli, primjera koji bi mogli objasniti tvrdnju o posljedicama njegove upotrebe.

Promjene u poimanju pojma mentaliteta naći ćemo (i) u našim društvenim i humanističkim znanostima. Tako u Filozofskom rječniku što ga je uredio Vladimir Filipović 1965. godine postoji natuknica o mentalitetu u kojoj stoji da je riječ o općem psihičkom ustrojstvu, odnosno globalnom duhovnom liku nekog pojedinca ili zajednice, njihovom tipičnom načinu doživljavanja, mišljenja, vrednovanja, ponašanja. Dapače, tvrdilo se da su razlike u mentalitetu (nastale iz različitih nasljednih dispozicija, različitih utjecaja prirodne, etničke i kulturne okoline, različitih tradicija, različitog odgoja itd.) izvanredno značajan faktor u oblikovanju odnosa među pojedincima i još više među zajednicama, te da su suprotnosti koje se interpretiraju kao sukobi interesa ili oprečnosti ciljeva često samo nesporazumi među različitim mentalitetima (Filipović 1965: 252). Na tom tragu je i suvremeno tumačenje globalizacijskih sukoba gdje se, preklopljen i djelomično zamijenjen pojmom identiteta (usp. Vrcan 1999), "mentalitet" uzima kao ključan element konflikata u doba globalizacije, kada se "svi društveni sukobi vode primarno oko zaposjedanja identiteta" (Paić 2005: 134). Gotovo da bismo, parafrazirajući Fredrica Jamesona, mogli reći da ako je postmodernizam bio kulturna logika kasnog kapitalizma, onda je identitet logika globalizacije. I zaista, od tvrdnje da su suprotnosti koje se interpretiraju kao sukobi interesa ili oprečnosti

${ }^{4} \mathrm{O}$ tomu vidi Ivan Čolović. 2014. Rastanak s identitetom. Beograd: Biblioteka XX vek, str. 106-110; posebno: "To bi moglo da znači da se istraživanje orijentalističkog diskursa iscrpljuje analizom i dekonstrukcijom njegovog narativa i da tu zaista 'nema ničega izvan teksta', dok se u slučaju balkanizma nameće potreba da se s poststrukturalističke dekonstrukcije narativa koji ga čine pređe na istoriografsku analizu realija, s pretpostavkom da ta dva pristupa nisu nužno nekompatibilni" (isto: 107-108). 
ciljeva ustvari često samo nesporazumi među različitim mentalitetima, pa do Huntingtonovih "sukoba civilizacija" put uistinu nije pretjerano dug.

Nedoumice oko važnosti pojma, međutim, rastu čim posegnemo za novijim rječnikom filozofije, onim A. R. Laceya iz 1996. godine, gdje pojma mentaliteta uopće nema. Slično je i s psihologijskim određenjem mentaliteta. Naime, Psihologijski rječnik iz 2005. godine pod natuknicom mentalitet ima tek jednu rečenicu pri čemu se pojam nedvosmisleno diskvalificira kao neznanstven - onaj koji se javlja samo u "popularnom", svakodnevnom govoru. ${ }^{5}$ No posegnemo li pak za klasičnim djelom naše ranije socijalne psihologije, onim Mladena Zvonarevića iz 1981., nalazimo da tu mentaliteta ne samo da ima (pojavljuje se u sintagmi "socijalni mentalitet"), nego mu je posvećeno čitavo, i ne baš ni malo poglavlje u okviru analize socijalizacije. Kaže se da je to, ni manje ni više, nego jedna od središnjih kategorija socijalne psihologije. Doslovno: "Sami rezultati socijalizacije sadržani su u kategoriji socijalnog mentaliteta, koja je jedna od središnjih kategorija socijalne psihologije" (Zvonarević 1981: 201). ${ }^{6}$

Međutim, u novijoj literaturi, dapače onoj koja se drži tako važnom da je u nas određena kao udžbenik - Uvodu o socijalnu psihologiju što su ga uredili Miles Hewstone i Wolfgang Stroebe (2001), a od kojeg se onda očekuje i prikaz novijih dostignuća u toj znanosti, "mentaliteta" nema u indeksu pojmova. Da se jedan pojam sa "središnje kategorije" sroza na "popularni izraz" u samo dvadeset četiri godine ne mora biti čudno s obzirom na brze promjene znanstvenih paradigmi u drugoj polovici dvadesetog stoljeća. Ipak ostaje očita obaveza istražiti što se to dogodilo s "mentalitetom" u socijalnoj psihologiji. Je li, naime, doista postao posve neupotrebljiv ili je samo zamijenjen preciznijim pojmovima?

U Osnovama političke psihologije Ivana Šibera nalazimo pojam socijalnog mentaliteta i to u analizi strukture svijesti pojedinih socijalnih grupa. Marxova teza da "ne određuje svijest ljudi njihovo biće, nego obrnuto - njihovo društveno biće određuje njihovu svijest", piše Šiber, našla je empirijsku potvrdu u suvremenim istraživanima političkog ponašanja. Tako Lazarsfeld, analizirajući rezultate empirijskih istraživanja izbornog ponašanja, kaže:

Kod Amerikanaca je uobičajena misao da je čovjek jedino ono što on misli da jest, misao koja odražava tipično američko vjerovanje u neograničene moguć-

\footnotetext{
5 "Popularni izraz koji označuje način mišljena i reagiranja karakterističnim za neku osobu, društvenu skupinu ili etničku grupu” (Petz 2005: 254).

${ }^{6}$ Zvonarević u posebnom odjeljku piše o socijalizaciji te je definira kao “proces u toku kojeg individuum - interakcijom sa svojom socijalnom sredinom - usvaja znanja, vještine, navike, stavove, vrijednosti i druge spoznaje, koje su potrebne za uspješno funkcioniranje u sredini u kojoj živi” (Zvonarević 1981: 201), rezultat čega je onda upravo "socijalni mentalitet", pojam koji obuhvaća kako utjecaj nasljeđa i okoline, tako i samoaktivnost određenog individuuma. Pojam je, piše Zvonarević, vrlo važan budući da je "proučavanje socijalnog mentaliteta pripadnika pojedinih socijalnih skupina osnova za sva socijalnopsihološka proučavanja socijalnih grupa na individualno-psihološkoj razini” (isto: 202).
} 
nosti i tendenciju stalnog napredovanja. Mi smo našli upravo suprotno: čovjek misli politički onako kakav je socijalno. Socijalne karakteristike određuju političku preferenciju. (Šiber 1998: 197)

Dakako da tu ne postoji nikakav automatizam, "ali da postoje značajne razlike u 'načinu mišljenja', odnosno sadržajima 'grupne svijesti', uvjetovane pripadnošću različitim socijalnim grupama, izvan je svake sumnje” (isto).

Time smo ponovno, sada i kod Šibera, već na skliskom terenu prvo predrasuda, a onda i stereotipova: valja preciznije vidjeti kako bi se razlikovao eventualni realno postojeći socijalni mentalitet od predrasuda i stereotipova o svojoj i o drugim društvenim grupama, to jest kako bi se razmotrili mogući stereotipovi o pojedinim mentalitetima.

Time dolazimo do nezaobilaznog istraživanja stereotipova u novijoj socijalnoj psihologiji, koje se definiraju kao "zajednička vjerovanja o personalnim atributima, obično o osobinama ličnosti, ali često i o ponašanju neke grupe ljudi" (isto: 199). Tako bi, čini se, istraživanje stereotipova bilo značajna dopunska obaveza svakomu tko se misli baviti nekim određenim "mentalitetom", odnosno eventualnim ukupnim rezultatom socijalizacije, bilo da se "mentalitet" pripisuje svojoj ili drugim društvenim grupama. Očita su, naime, mimoilaženja između moguće realno postojećeg nečijeg globalnog duhovnog lika s jedne strane, i zajedničkih vjerovanja o tom "liku" s druge strane, pa se čini da je već u samom pristupu potrebno uporno istraživati stereotipove o mentalitetu (mentalitetima).

Probleme predrasuda i stereotipova Šiber ipak ne dovodi u vezi s mentalitetom, nego ih smješta u odjeljak o psihologiji nacionalnog. Uvjerenja i sudovi do kojih se dolazi socijalizacijom, naime, mogu biti utemeljeni $u$ tradiciji vlastite grupe, ali ih ono ne čini istinitima. Šiber predrasude dijeli na tradicionalne predrasude (one koje se preuzimaju u procesu socijalizacije kao dio kulturnog nasljeđa), konformističke predrasude (one koje prevladavaju u nekoj grupi a vezane su za potrebu pojedinca da pripada toj grupi) i frustracijske predrasude (gdje se vlastito nezadovoljstvo ili krivnja projiciraju na pripadnike drugih naroda). Zatim se navodi pet stupnjeva očitovanja predrasuda: ocrnjivanje ili ogovaranje, izbjegavanje odnosno socijalna distanca, zatim diskriminacija, fizički napad i, na koncu, istrebljenje - pa se slijedom toga valja čuvati olakog govorenja o nekom ili nečijem mentalitetu, odnosno govorenja koje ne vodi računa o mogućem preklapanju mentaliteta s predrasudama o svom ili tuđem mentalitetu. K tomu, što je poseban problem, stereotipovi prividno omogućuju razlikovanje između pripadnika različitih društvenih grupa, ali zato sasvim onemogućavaju razlikovanje između pripadnika iste grupe (isto: 118).

Šiberov pristup ne spada u novije. Već osamdesetih godina prošlog stoljeća s etničkim, odnosno "nacionalnim karakterom" stajalo je tako da se raz- 
matrao u okviru etničkih stereotipova i predrasuda. Nikola Rot je, na primjer, naglašavao da su ocjene o osobinama pojedinih naroda pojednostavljene $\mathrm{i}$ neadekvatne, rigidne i teško promjenljive. Funkcija im, pisao je, međutim nije beznačajna, što onda može objasniti njihovu raširenost. Kao najvrednije teorije o uzrocima trajnosti predrasuda navodi društvenopovijesne teorije, a posebno Allportovu teoriju eksploatacije: predrasude se formiraju kod one društvene grupe koja ima povlašteni položaj i u čijem je interesu širenje predrasuda prema određenim grupama.

Iz sasvim određenih ekonomskih razloga razvijaju se, na primjer, koncepcije o inferiornosti kolonijalnih naroda kojima vlada metropola. Takva tobožnja inferiornost opravdava zadržavanje vlasti nad kolonijama. Različite varijante rasnih teorija stvaraju se upravo zbog toga da bi se, ukazujući na tobožnje nedostatke i negativnosti određenih manjina, te manjine držale u neravnopravnom položaju i eksploatirale. Govori se, na primjer, da Crncima ne treba davati veće plate jer će ih nekorisno rasipati; da bi Portorikanci, kad bi imali više novaca, samo više pili i više se kockali, i slično. Postojanje predrasuda i diskriminacija određenih grupa daje sasvim određene i praktične prednosti grupi koja takve predrasude širi. Za nju je ekonomska dobit iz takvih predrasuda očigledna. I nacistički progoni Židova pružali su onima koji su se takvim progonima pridružili korist, jer su omogućavali da dođu do njihove imovine i do njihovih položaja. Primjera koji ukazuju na ove vrste društvenih korena predrasuda ima mnogo. Španjolski konkvistadori, koji su nemilosrdno pljačkali novootkrivene zemlje Srednje i Južne Amerike i ubijali domoroce Indijance, činili su to navodeći da Indijanci i nisu ljudi u istom smislu kao Španjolci, pa da kršćanski princip da ne treba ubijati i da u svim ljudima treba gledati braću - ne važi i za Indijance. (Rot 1989: 403)

Iz svega Rot izvodi zaključak prema kojem, kad je riječ o bilo kojoj osobi “[p] ostojeća socijalna situacija je također faktor u njenoj socijalizaciji i može, također, biti determinanta njegovih koncepcija. Iza ovih snaga leže drugi važni, ali više udaljeni, uzroci utjecaja. Oni uključuju društvenu strukturu u kojoj osoba živi, dugotrajne ekonomske i kulturne tradicije, kao i nacionalne i povijesne utjecaje u toku dugog perioda" (isto: 405-406). ${ }^{7}$

${ }^{7}$ Grupna svijest, pak, ima tri razine: razinu socijalnog mentaliteta, razinu grupne svijesti i razinu ideologije grupe. Za socijalni se mentalitet kaže da je kao naziv neodređen te da je blizak pojmovima socijalnog karaktera, psihologiji naroda, nacionalnog karaktera, a u području političke psihologije - političkoj kulturi, no, koliko god bile različite, ipak sve spomenute koncepcije polaze od pretpostavke da je pojedine grupe moguće razlikovati s obzirom na psihičke osobine njihovih članova. Šiber ističe da "ono što je bitno u ovom određenju jest činjenica postojanja niza distinktnih osobina jedne grupe prema drugoj, dakle riječ je o ukupnosti psihičkih osobina, ali u isto vrijeme pojedinci, pripadnici te skupine, ne moraju biti svjesni postojanja tih osobina i razlika prema drugima. [...] Odlučili smo se za pojam socijalnog mentaliteta jer je on najširi i karakteristika je svih grupa, neovisno o tome na čemu se temelji grupna pripadnost" (Šiber 1998: 199). 
Na prigovor kako se tom koncepcijom ne može objasniti to da predrasude često nisu usmjerene i na one dijelove vlastitoga naroda koji se eksploatiraju, može se odgovoriti tvrdnjom da se predrasude šire zbog toga što koriste vladajućoj grupi da održi svoje pozicije. Ona ima korist od predrasuda već i time što nezadovoljstvo velikih dijelova vlastitog naroda širenjem predrasuda prema drugim narodima usmjerava u pravcu koji za vladajuću grupu nije opasan pa svoje vlastite teškoće rješava na taj način što razvija neprijateljstvo prema manjinama ili određenim etničkim grupama. Predrasude, u tom slučaju, služe za pomicanje nezadovoljstva stanovništva radi toga da bi se sačuvala vlastita privilegirana pozicija.

\section{POVRATAK POJMA U PROSTOR POLITIČKOG}

Problematičnost našeg sveobjašnjavajućeg pojma vidljiva je čak i nakon posve ovlašne analize njegove upotrebe u prostoru javne komunikacije, $u$ prostoru najdublje povezanosti političkog govora i javnog mnijenja. Iz obilja primjera uobičajenog pozivanja na "legendarni mentalitet", dovoljno je razmotriti samo nekolicinu primjera. I to ne bilo čijih, nego osoba za koje je razumno pretpostaviti da uistinu znaju o čemu govore. Događa se, tako, da u Hrvatskoj sociolozi govore o tomu da je Split najprecizniji detektor težine nevolja s kojima se sučeljava današnja Hrvatska i to zbog toga što je "Split južnjački, ekstrovertirani grad". ${ }^{8}$ Čuveni se masovni prosvjedi u Splitu 2001. godine tumače kulturnomentalitetnim razlozima, naime, time da je u samom Splitu snažno prisutna tradicionalna plemenskodinarska kultura, osobito u zaleđu Dalmacije i na jugu $\mathrm{BiH}$, što da je još tridesetih godina (uspješno!) analizirao Dinko Tomašić. Tako se, kao i danas vrijedne, u sociološkim analizama preuzimaju i Tomašićeve temeljne kategorije, a sve da je to u Splitu osobito uočljivo jer je to grad koji svoje traume i proturječja jače i otvorenije (temperamentnije?) izražava. ${ }^{9}$ Nastoje se dekonstruirati i poneki mitovi pa

8 "Evidentno je da su posljednjih godina eskalirale raznovrsne traume življenja u Splitu, koji je od velikih gradova u Hrvatskoj socijalno najugroženiji i ima najveće probleme”, izjavio je Dražen Lalić (Zvonimir Krstulović: “Treba osnovati poglavarstvo splitskog spasa!”, razgovor s dr. Draženom Lalićem, Slobodna Dalmacija, 23. srpnja 2001.). Opisujući i objašnjavajući spomenute splitske traume, Lalić govori o "urbanoj shizofreniji" i to uspoređujući svoje dojmove o dočeku Gorana Ivaniševića kada je "Split zaista zasjenio pustu Londru", s jedne strane, i s druge strane dojam o danima nakon proslave kada "sam šetao gradom i činilo mi se da mogu rukom napipati nešto kao veliki zloćudni tumor, depresiju i beznađe ljudi". A činjenicu da je i inače, uslijed raznih "ekscesa", pažnja svekolike javnosti Hrvatske sve češće usmjerena spram Splita, Lalić objašnjava time što se upravo "u Splitu najzornije i najdramatičnije izražavaju problemi Hrvatske" i to zbog toga što je "Split južnjački, ekstrovertirani grad", za razliku od, na primjer, Rijeke koja je "sjevernjački, introvertirani grad".

${ }^{9} \mathrm{U}$ vezi s čuvenim masovnim prosvjedima u Splitu, Lalić je ustvrdio kako smještaj prosvjeda baš u Splitu nije slučajan, a kao objašnjenje za to ponudio je više razloga. Prvi - da je na vlasti u Županiji HDZ, s tim da je u Splitu postigao bolji rezultat nego u drugim velikim gradovima. Drugi - da je većina splitskih 
se kaže da, na primjer, mit o fetivim Splićanima i Vlajima oduvijek zamagljuje bit problema, a on je u činjenici da postoje ljudi koji su u stanju prihvatiti urbani način života i oni koji to ne žele. ${ }^{10}$ Čak i najzadrtiji "fetivi" Splićani dopuštali su da nakon određenog razdoblja življenja u Splitu “Vlaji”, ili barem njihova djeca, mogu prihvatiti urbane norme ponašanja - rijetko se koga optuživalo da to čak niti ne želi.

I u prostoru javne komunikacije stalno su "u igri” neki mentalitet i neki temperament kao njegov dio. Dobrim su povodom da se sada upitamo i o sociološkom objašnjavanju današnjih društvenih i političkih činjenica pojmom mentaliteta i pozivanjem na Tomašića, čak i ako se mentalitetu ne pridaje važnost jedinog uzroka društvenim događanjima u suvremenoj Dalmaciji, nego bi eventualno bio njihov kulturni okvir. Katarina Luketić podsjeća na

medija desne orijentacije. Treće, da je Split izrazito socijalno ugrožen jer u njemu, prema broju stanovnika, ima oko dva i pol puta više nezaposlenih nego u Zagrebu. Četvrto je objašnjenje vezano za kulturnomentalitetne razloge: "Kulturno-mentalitetni razlozi bitan su činitelj tih prosvjeda, jer oni nisu bili vezani samo za Split i Županiju nego i za čitav južni dio hrvatskog kulturno-političkog prostora, u što ubrajam, uz otoke, priobalje i Dalmatinsku zagoru, i južni dio BiH, odnosno prostor koji neki nazivaju Herceg Bosnom. U samom Splitu snažno je prisutna tradicionalna plemensko-dinarska kultura, osobito u zaleđu Dalmacije i na jugu BiH. Još 30-tih godina Dinko Tomašić pomno je analizirao razlike između dinarske i zadružne kulture. On je već tada uočio opasnost da sela osvoje gradove i da doseljenici nameću svoje kulturne osobine gradskom stanovništvu i tako ga dewesterniziraju, kao i cijele gradove. Ovi prosvjedi već tko zna koji put aktualiziraju Tomašićeva zapažanja i upozorenja o dinarskoj kulturi u kojoj važno mjesto zauzimaju kult oružja i herojski kodeks, težnja za dominacijom, netolerantnost prema suparnicima, urotništvo i sklonost prema revolucionarnim zahvatima, ovisnost o uzbuđenjima i senzacijama. Štošta od toga manifestiralo se u prosvjedima u vezi sa 'slučajem Norac'. [...] Nakon Tuđmanove smrti, a osobito nakon političkih promjena 3. siječnja i predsjedničkih izbora, otvorio se prostor za zadovoljavanje nostalgije za herojima, koja je bila svojstvena dijelu ljudi, osobito onima koji su bili aktivni u Domovinskom ratu i izdanak su te dinarske kulture kojoj trebaju heroji i mitovi. [...] Na splitskom skupu bilo je i ljudi odjevenih u narodne nošnje, s kuburama, jedan je čak došao na konju, pjevale su se pjesme u desetercu, guslari su gudili. [...] Split je kulturno jako ambivalentan, pa i shizofren grad. U njemu su snažne i tradicionalna i moderna kultura. To nije slučajno jer je Split 70-tih i 80-tih doživio velike demografske promjene i u njegovu sadašnjem stanovništvu, prema nekim istraživanjima, ima čak oko 40 posto ljudi iz dinarskog zaleđa. Dio je potpuno prihvatio urbani način življenja, dio samo selektivno, dok mnogi kao da su građani samo po prebivalištu. [...] Dinarska plemenska kultura ne poštuje zakon, opire se vlasti, ne prihvaća autoritete, sklona je pljački i hajdučiji. U kulturnom sklopu tih ljudi to je kodirano generacijama i sada se samo masovno i javno izražava. Ako im je Domovinski rat svet, neupitan im je i svaki junak ili sudionik rata. Naravno, s tim se računalo i to je temelj manipulacije kako bi se tražilo nešto što je pravno i civilizacijski posve neosnovano jer se ratni zločini ne mogu abolirati. Jasno je da se moderno društvo, jedino u kojem možemo ostvariti visok životni standard i ostale tekovine razvijenoga zapada, ne može graditi na emocijama, mitovima i svetostima, jer se tako čini velik civilizacijski korak unatrag, koji je, uostalom, 90-tih i napravljen" (Nina Ožegović: "Splitski sociolog o desničarskim prosvjedima”, Nacional, 20. veljače 2001.). Iako Lalić navodi više razloga za čuvene "splitske događaje", upadljiva je razlika u opširnosti, u odnosu na ostale, posljednjeg uzroka masovnih prosvjeda u Splitu uz izravno pozivanje na Tomašićeve kategorije dinarske i zadružne kulture.

10 “Osim toga, više je pokazatelja da su fetivi Splićani svoj pasivni i nepoduzetni mentalitet prenosili na došljake nego da su došljaci utjecali na mentalitet grada. Priča o Vlajima zapravo je alibi za pasivnost, koji je davno izmišljen pa funkcionira kao kulturološka i folklorna činjenica. Dovoljno je malo nabrajati značajne Splićane, rođenjem Vlaje, pa vidjeti kako stvari stoje: Ivan Meštrović, Luka Botić, Ivo Tijardović, Vladimir Beara... Jesu li oni gradili ili razgrađivali splitski identitet? Mit o fetivim Splićanima i Vlajima oduvijek zamagljuje bit problema, a on je u činjenici da postoje ljudi koji su u stanju prihvatiti urbani način života i oni koji to ne žele" (Lalić u Miljenko Jergović: "Split je grad podijeljen između Thompsona i djece partizana", Globus, 27. lipnja 2003.). 
to da je Tomašić u Hrvatskoj "otkriven" početkom devedesetih kada njegove ideje promoviraju i reafirmiraju sociolozi poput Slavena Letice i Stjepana Meštrovića,

nalazeći u njima uporište za mentalitetske, fiksirane slike i uopće koncepcije koje afirmiraju rigidne teze o homogenom, zatvorenom hrvatskom nacionalnom identitetu, sasvim suprotnom od srpskoga. Tomašićeva je teorija u to vrijeme bila i politički korisna i unosna jer se interpretirala kao znanstvena verifikacija oficijelnog političkog i medijskog diskursa o uzrocima rata i identitetima na ovim prostorima. (Luketić 2013: 128-129)

Nakon dugogodišnje prešućenosti, o radu Dinka Tomašića i njegovim koncepcijama dinarske i zadružne, ravničarske kulture pisano je u nas opširno i temeljito, dapače, vođene su i polemike. Jedan je broj Društvenih istraživanja (6/1993) posvećen njegovoj sociologiji, a u istom je časopisu (2/1992) o Tomašićevoj etnosociologiji Aleksandar Štulhofer objavio opširan rad, dok je godine 1997. tiskan reprint Tomašićeva Političkog razvitka Hrvata (a u njemu kao prilog popis ne baš malog broja studija o Tomašiću ili radova u kojima se o njemu raspravlja).

Međutim, uz sve pohvale radu Dinka Tomašića koje su i tu ispisane, ${ }^{11}$ gotovo opći zaključak ipak nije baš takav da bi se koncepcije Dinka Tomašića mogle neupitno i bez ikakve distance koristiti u tumačenju današnjeg društva - čak i ako se koriste samo kao dopunske. Primjerice, Aleksandar Štulhofer piše da je Tomašićev model "uzet u cjelini, obilježen nedokazljivošću, statičnošću i redukcionizmom, a sadrži i očite proizvoljnosti. Iz tih razloga, predložena etnosociološka analiza nije uspjela izboriti mjesto unutar korpusa suvremenih socioloških teorija i pristupa" (Štulhofer 1997: 199). Doduše, Štulhoferova polemika s Hrvojem Lorkovićem kazuje da ima suprotnih mišljenja te da su se Tomašićevi modeli pokušavali primijeniti, kao objašnjenje, za rat između Srbije i Hrvatske, no Štulhofer razložno odgovara da je, istina, "moguće iskreno vjerovati u nepromjenjivost kulturnog naslijeđa, odnosno u ideju prema kojoj su kolektivne kulturne osobine 'zamrznute' u vremenu. Posve je druga stvar, dakako, može li se ta vjera poduprijeti znanstvenom argumentacijom. (Lorković je objelodanio prvo, ali se nije potrudio oko ovog drugog; Inglehar-

\footnotetext{
${ }^{11}$ Nešto je odmjereniji stav Dunje Rihtman-Auguštin prema kojem, iako se danas antropologija i etnologija ne bave konstrukcijama psihičkih tipova te se "toga tek ponekad za svoje potrebe dohvate neki javni djelatnici", a i istraživanja nacionalnog karaktera također su se pokazala manjkavima te se suvremenim znanstveno temeljenim istraživanjima mentaliteta bavi moderna historiografija, a istraživanja se zasnivaju na podacima o dugotrajnim povijesnim procesima, ipak je to donekle predvidio i Tomašić. Međutim, piše ona, "kad bismo se danas latili tih poslova - a trebali bismo - morali bismo to učiniti ne tendenciozno kao Cvijić, ali i temeljitije nego Tomašić. No čini mi se da bi Tomašićeve hipoteze mogle poslužiti kao izazov" (Rihtman-Auguštin 1993: 971).
} 
tovi empirijski podaci (1990) upućuju da bi to bio uzaludan trud)" (Štulhofer 1993: 1000). Također,

[č]injenica da etnosociološka tumačenja narodne psihe danas prilično slabo kotiraju u društvenim znanostima govori o barem jednoj činjenici. 0 problemu koji te teorije imaju s konceptom provjerljivosti. Budući da ga ne uspijevaju preskočiti, neplodne su i interes za njih odumire. (U znanstvenoj zajednici, dakako.) Stoga, ako Tomašić u mojim radovima "ne dolazi na svoj račun" onoliko koliko bi to Lorković želio, onda je to, nadam se, isključivo posljedica napretka sociološke spoznaje u posljednjih pola stoljeća [...] (isto)

Kritičarima Tomašićevih i sličnih koncepcija, dakako, ne mora se vjerovati na riječ iako je, možda, dovoljno pažljivo iščitati ako ne baš Ingleharta, ono svakako Geerta Hofstedea, ali je uistinu teško zanemariti sve one primjedbe koje su tim koncepcijama upućivane i istraživanja koja su ih opovrgavala, i to ne od danas.

Već spominjani Šiber, na primjer, potvrđuje da su pojmovi "psihologije naroda" i "narodnog karaktera" nekritički preuzimani s namjerom da iskažu posebnost pojedinih naroda, da takvi pristupi imaju svoje rodonačelnike u Lazarusu i Steinthalu i zatim Ratzelu. Ovaj posljednji na kraju 19., odnosno početkom 20. stoljeća (!) naglašava ulogu tla koje neumitno određuje karakter jednog naroda te prvi rabi tezu o "životnom prostoru", a takvim su pristupima na ovim prostorima bliski radovi J. Cvijića, V. Dvornikovića i D. Tomašića. U vezi s tim, pak, Šiber generalno ističe da je teško "ne prihvatiti davno izrečene riječi Johna Stuarta Milla (1848.): 'Od svih vulgarnih oblika bježanja od razmatranja posljedica efekata socijalnih i moralnih utjecaja na ljudsku svijest, najvulgarniji je onaj koji pripisuje raznolikost u ponašanju i karakteru urođenim, prirodnim razlikama'” (Šiber 1998: 95). A tako je, čini se, ostalo do danas. I uporno se obnavlja. ${ }^{12}$

${ }^{12}$ Zanimljivu potvrdu težnje stereotipnog mišljenja prema stalnosti zaista ćemo naći u mnoštvu istraživanja, pa i u nas. Željka Kamenov i Dinka Čorkalo istražile su sadržaj nacionalnih stereotipova studenata psihologije hrvatske nacionalnosti. Studenti su ispitani 1991. godine pa 1993. godine i ponovno 1996. godine, nakon završetka rata. U uvodu su naglasile da je predrasude iznimno teško mijenjati, "i to kako njihovu emocionalnu komponentu tako i njihov kognitivni sadržaj - stereotipove (Hamilton and Sherman, 1996)" (Kamenov i Čorkalo 1997: 361) također i to da takvo pojednostavljeno percipiranje ljudi na osnovi njihova pripadanja određenoj grupi ima svoju adaptativnu funkciju, ali i niz nedostataka. Nedostaci su, tvrde autorice, najuočljiviji u posljedicama takvog uopćavanja. Ispitivanje je opisalo sadržaj stereotipova pa se, između ostalog, hrvatska nacija označavala kao rodoljubna, umjerena, ustrajna, istinoljubiva, gostoljubiva i civilizirana. Slovenci su se opisivali kao sposobni, poslovni, organizirani i pedantni, Srbima se pripisivala želja za dominacijom, nepopustljivost i moć, zatim proračunatost, nametljivost, vlastohlepnost, osvetoljubivost i upornost, dok su za Albance birani atributi samokažnjavanja, napornog rada i trpljenja te pasivnosti, zatvorenosti, neobrazovanosti, radinosti, štedljivosti, discipliniranosti i neprihvaćenosti. U sva tri istraživanja ispitanici su Srbe i Albance označili značajno neprijateljskijima od vlastite nacije. Autorice ističu zanimljivost mijenjanja predodžbe o Slovencima - s vremenom ih se doživljava sve manje prijateljskima, ali je opći zaključak da je gotovo sve drugo ostalo isto. "Sadržaj svakog stereotipa ostao je više-manje jednak, čime se ponovno potvrdila trajnost stereotipova kao sklopova uvje- 
Za našu je temu važno podvući očitu činjenicu da se naklonost ili netrpeljivost prema drugima ne ograničava na "tumačenje" tih drugih, nego se proteže i na razumijevanje vlastite društvene skupine i sebe samih te se često autostereotipovi pokazuju još otpornijima od stereotipova o drugima.

Jasno je da postoje važni razlozi zbog kojih se u nas obnavljaju pristupi koji pokušavaju revitalizirati pojmove "nacionalnih karaktera", kakav je onaj Dinka Tomašića, a na jedan od bitnih upozorio je Aleksandar Štulhofer. Riječ je o nastojanju da se objasni posljednji rat, naše najtraumatičnije iskustvo posljednjih desetljeća. Štulhofer drži da je u vezi s jednom od najzastupljenijih predodžbi hrvatskog mnijenja, onoj o fundamentalnim i nepremostivim razlikama između Hrvata i Srba (i to tolikim da je i sam rat izrazom upravo te temeljne različitosti i inkompatibilnosti dvaju kulturnih krugova, "evropskog, kojem pripada hrvatski narod, te onog balkanskog, bizantsko-otomanskog, kojeg reprezentiraju Srbi" što su sve manje-više Tomašićeve kategorije), ipak riječ samo o blokiranju racionalnosti (Štulhofer 1992: 300). A kada je, iz bilo kojih razloga blokirana racionalnost, onda

[n]a ispražnjeno mjesto spremno uskače mitsko mišljenje sa svojim binarnim suprotnostima (C. Levi-Strauss). "Mi" i "oni" prestaju biti jednakovrsni akteri čije se ponašanje može protumačiti uobičajenim postupkom. Razdjeljuje ih fundamentalna razlika: "naš" razum više nije od pomoći jer se "oni" ne ponašaju racionalno. Naprosto su drukčiji - jer inače ne bi učinili to što su učinili. Tomašićeva naracija o suprotstavljenim kolektivnim silama, koje raznorodno oblikuju pojedince, savršeno se uklapa u izloženi kognitivni okvir. Iz perspektive ratom pogođenih, postuliranje dubokih kulturnih i kolektivnopsiholoških razlika potpuno opravdava deficit analitičnosti koja se, uostalom - i to valja naglasiti - sudara s afektivnim kaosom u kojem se nalaze. Smatramo li opisanu nemogućnost drukčijeg nošenja s ratnom katastrofom najodgovornijom za "mitsko mišljenje" nešto ostaje nepromijenjeno. Sâmo vjerovanje, koje može biti pogibeljno [...] (isto: 311)

Da je uistinu riječ o problematičnom pristupu tumačenja suvremenih događaja tvrde i drugi analitičari. Ne bez razloga, Karl Kaser piše o "okamenjivanju diskursa" i selektivnoj stvarnosti i kod Cvijića i kod Tomašića, a također i u radu Stjepana Meštrovića koji je od Tomašića preuzeo ideju o planinskim i ravničarskim ljudima te "ponovno otkrio njega i njegove teorije".

renja o osobinama skupina ljudi. Promijenila se, međutim, emocionalna komponenta ispitivanih etničkih stavova, to jest pojačale su se predrasude. Vidimo da u proteklih pet godina ispitanici nisu promijenili stav o vlastitoj naciji, ali je njihova percepcija pripadnika svih ostalih ispitivanih nacija postala sve negativnija" (isto: 368-369). Autorice izražavaju uvjerenje (nadu), a temelji se na nalazima čuvene princentonske studije u kojoj je pokazana promjena sadržaja stereotipova, da takvo psihološko udaljavanje od drugih grupa ipak nije trajno i nepromjenljivo. 
Meštrović tvrdi da je njegova argumentacija kulturalna, ali je ona, zapravo, politički motivirana. Koncepcija socijalnih karaktera koju on primjenjuje vodi polarizaciji dobra i zla, planinskog i ravničarskog čovjeka - i to tri desetljeća pošto su kulturoantropolozi ispitali takve etnografske predodžbe. (Kaser 2007: 240-241)

Kako bilo, ne bismo smjeli brkati, kao što se ipak događa u dijelu naše historiografije, Tomašićev i Cvijićev pristup s onim jednog Braudela, na primjer, na što također upozorava Kaser. Braudelov je pristup komparativan jer je za njega Balkan samo dio široke, mediteranske perspektive, on promatra mediteranske kulture kroz povijest, a uz to uzima u obzir i povijesne participante koji nisu strukturirani samo utjecajima sredine. Valja odvojiti Tomašićev pristup od kategorija "povijesti mentaliteta", "povijesti anonimnog čovječanstva" i "kolektivnog nesvjesnog" (Aries 1995: 149, 161) ili proučavanja povijesti "posredovanja i dijalektičkog odnosa među objektivnim uvjetima ljudskog života i načina na koji ga oni prepričavaju, pa čak i proživljavaju" - odnosno s "poviješću vizija svijeta” (Vovelle 1995: 166, 170). Riječ je o dobro poznatom i, pokazalo se, veoma produktivnom susretu historiografije i etnologije, sa svim odlikama koje je u taj odnos unio ne samo Braudel, a kojeg nema u starijim raspravama o "etničkim karakterima”. I Mirjana Gross i Miroslav Bertoša, da spomenem samo naše ponajbolje povjesničare, s uvažavanjem pišu o doprinosima "povijesti mentaliteta", a i sami su joj značajno pridonijeli, ali to nije ni u kakvoj vezi s tumačenjima "mentaliteta" kakvih možemo naći u nas. ${ }^{13}$

Da su predrasude i stereotipovi pa i mitovi više nego plodno tlo kojekakvim politikama pisali su brojni autori. Jedan od na ovim prostorima istaknutijih svakako je Ivan Čolović. U ogledima iz političke antropologije, nakon što je ustvrdio da su politički mitovi fenomen krize i kritičnih razdoblja društvenog života jer upravo tada osvajaju daleko veći prostor javne komunikacije, navodi riječi poljskog povjesničara Bronislawa Baczka "da suvremeni istraživači društva i politike, za razliku od francuskih studenata iz 1968. godine - koji su između ostalog tražili da mašta dođe na vlast (slogan: Vlast mašti!), znaju da je 'mašta oduvijek na vlasti'” (Čolović 1997: 80). Dapače, Baczko naglašava

${ }^{13}$ To možemo vidjeti na primjeru Bančeva priklanjanja pojmu "narodnog mentaliteta". Zanimljiva je, naime, njegova interpretacija takozvanog problema Srba-katolika u Dubrovniku (o tome vidi i Lorger 2010). Dok Šidak (Šidak i dr. 1968) spominje kako je grupa narodnjaka u Dubrovniku u vezi s nacionalnim oslobođenjem polagala glavnu nadu u tada najmoćniju državu Južnih Slavena, Srbiju, a i Stančić (Stančić 1980) svjedoči o nejasnim početnim stavovima narodnjaka kada nas upućuje na to da su početno Dubrovnik smatrali srpskim, a da su u Hrvate ubrajali i pravoslavno stanovništvo sjeverne Dalmacije, sasvim originalno tumačenje donosi Ivo Banac. Nakon što je spomenuo povijest dubrovačke vjerske netrpeljivosti prema pravoslavnima, kao i na "duboku" razliku srpskog i hrvatskog mentaliteta, za jednog od dubrovačkih Srba-katolika razlog za kršenje "vjerskog pravila” nalazi, osim u tomu da je bio Garašaninov agent, dodatno i u vjerskoj ravnodušnosti: "ne iznenađuje stoga što je takva vjerska ravnodušnost proizvela sklonost prema pravoslavlju” (Banac 1992: 48-79). 
da se svaka vlast, a osobito politička, "okružuje kolektivnim predstavama" te je za nju "područje imaginarnog i simboličkog od prvorazrednog strateškog značenja" (isto). Nama je ovdje značajno i Čolovićevo navođenje Bastideove tvrdnje da su "mitovi odgovori na pojave društvenih potresa, na tenzije unutar društvenih struktura, da su oni ekrani na koje grupe projiciraju svoje kolektivne strahove" (isto: 79). Poziva i na Bonazzijev stav da je mit zapravo realnost koju tek valja istraživati te zatim na Lauera koji svoju kritiku usmjerava na "primijenjenu, u političku praksu sprovedenu mitologiju, jer 'bukvalno pretakanje mita u djelo predstavlja opću opasnost"” (isto: 81). Sam je Čolović u skladu s tim sustavno, uporno i razorno analizirao suvremene srpske političke mitove. Bit Čolovićeve analize, međutim, nije isključivo u tomu što on istražuje same mitove, nego i što istodobno istražuje njihovu političku upotrebu. A to su dvije posve različite stvari i valja ih biti svjestan.

Dunja Rihtman-Auguštin ističe da se u Čolovićevu razlaganju srpskog političkog mita veoma lako, kao u ogledalu, može prepoznati isti takav, hrvatski (Rihtman-Auguštin 1998: 74). Ističe da su etnolozi

veoma mnogo pisali o mitu. Čini mi se da je sa stajališta etnologije svakodnevnice i sa stajališta političke antropologije moguće reći jedino to da su mitovi oduvijek postojali i da će uvijek novi nastajati oslanjajući se više ili manje na stare. Oni, naime, simbolima uvijek moraju priskrbiti davnu prošlost. Baš zato mitovi će uvijek imati posve određenu funkciju, često upravo onu političku: nemoguće je spriječiti, preduhitriti političku upotrebu mita. Dekonstrukcija mitova nije uništila mitove niti je ograničila njihovu političku upotrebu. No, znači li to da suvremeni etno-antropolog treba odustati od kritike i dekonstrukcije mitova? (Rihtman-Auguštin 1998: 75)

Ne samo da ne znači, nego će dekonstrukciju mita shvatiti kao etički imperativ. Ovdje nam je posebno zanimljivo, a za svrhu usporedbe s diskursom o Dalmaciji i njezinom mentalitetu te s dalmatinskim realijama, pratiti promjene u percepciji Balkana na koje je također upozorila Dunja Rihtman-Auguštin u tekstu "Zašto i otkad se grozimo Balkana? Od oduševljenja Balkanom i 'balkanskom braćom' kod pravaša do Balkana kao psovke u novijoj povijesti". Autorica naglašava da je diskurs o Balkanu prije svega politički te da se pojam Balkana oduvijek i upotrebljavao kao politički argument. Tekst je i metodološki zanimljiv: ponavlja se (kod Čolovića ranije uočena) teza da "Balkan ipak ne živi samo u imaginacijama; istinske kulturne razlike nalaze se i u stvarnosti, a oslonac su im povijesna iskustva duga trajanja" (Rihtman-Auguštin 1997: 34). Zbog toga ona predlaže da se obrasci predočavanja Balkana shvate samo kao dio znanstvene spoznaje uz istodobno promišljanje i istraživanje stvarnih povijesnih tokova (problematizira se, dakle, predočavanje Balkana i balkanski mentalitet, ali se zadržava pojam mentaliteta). Osim kod većeg broja autora u zborniku Balkan kao metafora, na upozorenje o političkoj 
upotrebi nalazimo i kod Katarine Luketić: "duhove Balkana su određeni akteri sustavno zamišljali, priče o njima održavali aktualnima i pomoću tih priča proizvodili svoje vrlo konkretne ciljeve" (Luketić 2013: 304).

\section{HUMORNO NALIČJE “DALMATINSKOG MENTALITETA“}

Koji se to "vrlo konkretni ciljevi" onda moguće kriju i iza, u uvodu spomenutih, a toliko proširenih stereotipova o dalmatinskom mentalitetu? Čak i najpovršnije čitanje stvarnosti Splita i Dalmacije, a nasuprot u uvodu spomenutih, raširenih samoopisa, ${ }^{14}$ pokazuje:

- da je "dalmatinski humor" najčešće, a od strane određenih grupa/slojeva/klasa, grubo i surovo ruganje bolesnima, nemoćnima i drukčijima, pa je, ustvari, riječ o neprihvaćanju drugih i drukčijih, što se često koristilo i koristi za najgrublji teror prema siromašnom ili po drugim osnovama isključenom stanovništvu te regije - i šutnju o tom teroru;

- da "ugledni" i utjecajni Dalmatinci malo kad iskazuju bilo kakvo suprotstavljanje jačima, bogatijima i moćnijima (pa se, na primjer, Alka trčala bez razlike svim vladarima na tom području), te da su oni među njima koji to ipak rade jednaka rijetkost kao bilo gdje drugdje;

- da je navodna ljubav prema Splitu obično izlika za nekritično glorificiranje svog i vlastitog - pa kakvo god bilo, da često skriva kampanilizam i da povećava netrpeljivost između Splita i ostalih gradova i sela Dalmacije, a služi okamenjivanju postojećeg stanja;

- da teza o pravim Splićanima i "splitskom kolinu" zapravo skriva duboku ksenofobiju etabliranih, "viših društvenih slojeva", ksenofobiju koja postoji sasvim ravnopravno uz tradiciju multikulturalnosti;

- da tijardovštine, osim u "Maloj Floramy", ima malo ili je nema uopće, a koristi se za prikrivanje i opravdanje pokušaja, opetovanih i upornih, provincijalizacije te regije u cjelini te, posebno, za prikrivanje stvarnih linija socijalnih sukoba. ${ }^{15}$

Ipak problem "dalmatinskog mentaliteta" potrebno je otvoriti i zato jer Dalmacija danas jest regija "u potrazi za potvrdom vlastita postojanja" $s$ latentno prisutnim posve drugim i drukčijim vrijednostima od opisanih, nametnutih i izmanipuliranih stereotipova. Moglo bi se, na primjer, dokazivati da su Dalmatinci (dakako, "niži" slojevi, grupe, klase) bili, a i danas

${ }^{14}$ Svi se navedeni opisi lako mogu naći kod raznih kroničara Splita i Dalmacije. Najpreglednije kod već spominjanog Kudrjavceva (2002) iako se Ča je pusta Londra... odnosi na prva desetljeća prošlog stoljeća. Međutim, da se tu malo ili ništa nije promijenilo pokazuje, među ostalima, Jurica Pavičić (2004).

${ }^{15}$ Isto tako, smiješno je brkanje mentaliteta i prostora. To što se zbog ugodne klime dobar dio društvenog života u Dalmaciji odvija na otvorenome ("eksterijer"), posve je pogrešno nazivati "ekstrovertiranošću“- riječi, istina, imaju isti korijen, ali nemaju isto pa čak ni slično značenje. 
su - pretežno - marljivi i vrijedni. Valja pogledati polja po otocima i Zagori i zamisliti koliko je napora i strpljenja trebalo (dakako seljacima) da se među kamenjem pronađu i održavaju "šake zemje". Sve one, istina, ružne, ali velike i skupe "kućerine" po selima Dalmatinske zagore valjalo je zaraditi teškim i ponižavajućim radom po Njemačkoj. Turizam, a bavljenje njime u nas se smatra vrhuncem lijenosti, na plus četrdeset je zabavna aktivnost samo turistima.

Ukratko, problem dalmatinskog mentaliteta otvoreno je pitanje kojeg u javnim raspravama za sada nema. Ono čega, međutim, ima i to u izobilju jest ozbiljna manipulacija stereotipovima.

Odavde nam je korisno krenuti prema zapletu jednog od najčuvenijih, a mnogi će se složiti, i najvrednijih romana današnjice, Ime ruže Umberta Eca, a koji se vrti oko druge knjige Aristotelove "Poetike", knjige o smijehu. U velikom dvoboju Jorgea i Vilima kazano je da Aristotel sklonost smijehu vidi kao dobru sposobnost, sposobnost koja može imati čak i spoznajnu vrijednost - jer nas tjera da se u sve bolje zagledamo te kažemo "eto, stvari su stajale baš tako, a ja to nisam znao" (Eco 1989: 381). Jorge pak želi uništiti upravo tu knjigu jer je Filozofova (naime Aristotelova, ime kojeg se u srednjem vijeku izgovaralo s velikim "F"), dakle, autoriteta koji svojim stavom može ugroziti Crkvu, a smijeh je slabost koju Crkva još i može podnositi kod priprostih, no kod obrazovanih bi taj smijeh mogao ukloniti strah. "Iz ove bi knjige", kaže Jorge, "mogla kresnuti luciferska iskra, kojom bi čitav svijet mogao planuti u novom požaru, i smijeh bi se ukazao kao novo, čak i Prometeju nepoznato umijeće što ukida strah" (isto: 382-383). A Zakon i Dogma, nastavlja Jorge temelje se na strahu. Što su, također, znali svi diktatori. I u čemu je, uostalom, Jorge mnogostruko u pravu. Kroz povijest se doista znalo pokazati da čak ni kontrolirani i dopušteni pokladni dani smijeha nisu bezopasni! "Pobune i ustanci često su se zbivali za vrijeme velikih svetkovina" (Burke 1991: 163), piše Peter Burke analizirajući upravo razdoblje poklada. "Naročito su u južnoj Evropi poklade bile najveći narodni praznik u godini, povlašteno razdoblje kada je ljudima dopušteno da barem jednom gotovo nekažnjeno kažu ono što misle", priča nam Burke, pa nastavlja, "[u] tim prilikama vlasti su bile itekako svjesne problema, što razabiremo iz brojnih edikata protiv nošenja oružja tijekom poklada" (isto: 148 ). ${ }^{16}$

Imajući, dakle, mišljenje o sebi kao o najduhovitijima u ovom dijelu svijeta, a možda i šire, Dalmatinci doista samom smijehu daju upravo onu vrijednost koju smijeh i zaslužuje. Kakva je, međutim, narav "dalmatinskog humora"?

\footnotetext{
${ }^{16}$ Slično shvaćanje smijeha, šale i dosjetke, naime, da istodobno ukidaju strah i imaju spoznajnu vrijednost, izražava i Freud u studiji Dosjetka i njen odnos prema nesvjesnom. U uvodu podsjeća na opsežnu literaturu o tim fenomenima te se slaže s tvrdnjama da dosjetka ima karakteristiku "neposredne zamjene zapanjenosti i prosvjetljenja" te "otkrivanja skrivenog" (Freud 1969: 11-12). Dapače, tvrdi da služi, između ostalog, i tomu da bi se na neopasan način iskazala agresija i kritika te čak pobuna protiv onih "koji se nalaze na višim položajima i polažu prava na autoritet" (isto: 107).
} 
Prvo što će zamijetiti imalo pažljiviji promatrač je zamjena i to zamjena humora za ismijavanje ridikula, što nije nepoznato i drugdje, ali je u Dalmaciji nerijetko (bilo?) izdignuto na razinu institucije. U Dalmaciji, u određenom povijesnom razdoblju i među određenim grupama, nisu ridikuli bili oni na "višim položajima koji polažu pravo na autoritet", čime bi bili "protivnici dostojni dosjetke" (isto: 107), nego su to, posve suprotno, bolesni, siromašni i nemoćni. ${ }^{17}$

Sljedeće je pitanje, stoga, je li ismijavanje ridikula u Dalmaciji, u određenom razdoblju i od strane određenih grupa i krugova, pretežno "komična lakrdija", dakle, možda ipak samo nešto glupo, ali bezazleno, ili je "brutalna sprdnja", nešto što je jako daleko od bezazlenog, te pripada načinu iskazivanja i potvrđivanja isključenosti iz društva objekta te brutalnosti. Odgovor na pitanje je li možda riječ o ovom drugom što ima dugu tradiciju i to ne samo u Dalmaciji, valja potražiti u povijesnim izvorima. Opisujući civilizaciju srednjovjekovnog Zapada, Jacques Le Goff, na primjer, navodi popis isključenih: "heretici, gubavci, Židovi, vještaci, sodomiti, bogalji, stranci, obespravljeni" (Le Goff 1998: 408-415). Za temu ridikulstva u Dalmaciji zanimljiv je osobito odnos prema bolesnima, invalidima i psihičkim bolesnicima, dakle, onima koji su bili najčešći objekti tog specifičnog "humora".

Invalidi doista pripadaju isključenima još od srednjeg vijeka.

Isključeni su također i bolesnici nadasve bogalji, sakati. U tom svijetu, u kojemu se bolest i sakatost drže izvanjskim znakovima grijeha, oni koje ona pogodi prokleti su od Boga, dakle i od ljudi. Crkva ih prima privremeno - dok ih ne smjesti u bolnice i općenito na vrlo ograničeno vrijeme - povremence hrani neke od njih - uglavnom na praznične dane. Drugima je jedini izvor sredstava za život prosjačenje i skitanje. (isto: 415)

Međutim, prema psihičkim bolesnicima srednji vijek ipak ima dvosmislen stav. "Jednom ih drži gotovo nadahnutima, a gospodarev zabavljač, koji će postati kraljevom ludom, postat će mu i savjetnikom. Seoska luda, u tome seljačkome društvu, fetiš je zajednice" (isto: 412) - pa su, dakle, dio društva,

${ }^{17}$ O subjektima šale i dosjetke također možemo štošta naći kod Freuda. Nakon što je ustvrdio da je dosjetka doista podesna za neizravne napade na ono što je veliko, dostojanstveno i moćno, u jednom kratkom odlomku napominje da dosjetke na račun manje vrijednih i nemoćnih osoba zaslužuju posebno tumačenje. Posebno, pita se jesu li su to protivnici dostojni dosjetke. Nalazi da je možda riječ o tome da se u toj vrsti dosjetki zapravo ipak cilja na institucije, moralne i religiozne propise i životna shvaćanja "koja uživaju takav ugled da se prigovor upućen na njihov račun ne može drukčije pojaviti do pod maskom dosjetke" (isto: 111). Prema tome, (možda, jer u toj stvari Freud nema jasan stav), dobra dosjetka u svakom slučaju mora imati "dostojan subjekt". A ismijavanje psihičkih bolesnika i bogalja, najčešćih objekata "dalmatinskog humora", vidimo, ne zadovoljava ni taj Freudov uvjet dobre dosjetke. Stoga mi se čini zanimljivom njegova analiza dosjetki o Židovima. One kojih su autori sami Židovi prema Freudovom su mišljenju doista dobre dosjetke, "dok se židovske priče drugog porijekla skoro nikada ne izdižu iznad razine komične lakrdije ili brutalne sprdnje" (isto: 147). Moguće je, dakle, da netko i negdje pod "humorom" shvaća i prakticira tek komičnu lakrdiju ili čak brutalnu sprdnju. 
nisu čak ni isključeni. "Veliko zatvaranje”, kako ga je nazvao Michel Foucault, dakle, utamničenje i izoliranje psihičkih bolesnika, događa se tek nakon "strašnog" srednjeg vijeka u 17. stoljeću pa prema tome njihova društvena isključenost ipak ima nešto kraću, iako poprilično dugu tradiciju - a prisutna je i danas (Foucault 1980). ${ }^{18}$

Ismijavanje i ruganje bolesnima (osobito duševnim bolesnicima), nemoćnima i drukčijima, dakle, doista jest dugotrajna, a i danas raširena, žalosna pojava kojom se bave razni istraživači ljudskog ponašanja, od pisaca "krimića"19 do sociologa, psihijatara i psihologa. Lako je uočiti da se agresivnost prema tim žrtvama i njihova društvena isključenost najčešće postiže i iskazuje kao ruganje i ismijavanje, te da pripada, da tako kažem, prvoj fazi okrutnosti koja prelako prelazi u drugu, to jest nesuosjećanje s njihovim patnjama, a zna prijeći i u treću fazu, srećom, danas ipak rjeđu - pokušaj njihove fizičke eliminacije. Isključenost bolesnih nije dalmatinski "specijalitet”. Pa ipak, iako samo poneki Dalmatinci ruganje nazivaju humorom, ostaje dojam da je u "dalmatinski mentalitet" upisano da su od ridikulstva stvorili instituciju kojom se hvale (ili za njom tuguju). Ne treba zaboraviti ni dubrovačke oriđinale, no, kad je riječ o Splitu, onda će nam uvid omogućiti jedan od ponajboljih kroničara splitskih običaja - Anatolij Kudrjavcev. Evo što piše o splitskom "humoru", prvo u knjizi Vječni Split:

U splitskoj šali, međutim, zbiljski postoje znaci brutalne agresivnosti [...] (Kudrjavcev 1985: 346)

Navika ruganja kao osnovni oblik općenja među ljudima običaj je koji će od Splita zauvijek stvoriti legendarno poprište bezočnih šala na račun tuđih slabosti, rasadnik bezbrojnih oriđinala što ih je neprestano otkrivalo dokono oko razularenih zlobnika osebujnog, odavno utvđenog stila života. A taj stil proizlazi iz gotovo bolesne potrebe da se od bližnjega napravi budala kako bi se dobilo na vlastitoj vrijednosti [...] (isto: 349)

Siromasi, duševni bolesnici i čudaci nigdje, ni u jednom našem gradu nisu takav predmet pažnje i ismijavanja, veli Danijel Dragojević. (isto: 358)

${ }^{18}$ Naime, analizirajući istraživanja uzroka duboko ukorijenjenog straha od duševnih bolesnika (i, posljedično, nastojanja da ih se stigmatizira i izolira) vršena sredinom prošlog stoljeća u SAD-u, Dušan Kecmanović nalazi da je taj strah realno posve nerazuman jer je svijet duševnih bolesnika u stvari svijet tragičnih usamljenika, društveno najbespomoćniji, a uz to posve nemoćan pružiti organizirani otpor. Tu je, piše Kecmanović, zapravo riječ o duboko ukorijenjenim - predrasudama, a tvrdokornost neumoljivosti društva prema bolesnima očituje se i u "više-manje trajnom neprihvaćanju onoga tko je, barem jedanput, bio 's onu stranu barijere', u zabranu patološkog. Ako ga čuvari patološkog (psihijatri, suci, čuvari zatvora, popravnih domova i sl.) i puste na drugu stranu, on će sobom ponijeti granicu: on će biti živa granica" (Kecmanović 1973: 100-101).

${ }^{19}$ Minette Walters je jedna od ponajboljih: u Čegrtuši (2002), koja se događa se u suvremenoj Engleskoj, skupina "normalnih" građana prvo okrutno muči, a onda i ubija osamljenu i bolesnu ženu, koja je k tome još i - Crnkinja. 
U potrazi za izgubljenim Mediteranom, kasnijoj Kudrjavcevljevoj knjizi, u poglavlju o "Šali" nema baš nikakvih primjera, ali ih zato ima u poglavljima nazvanim "Ruganje" i "Redikul" i mučno ih je prepričavati pa evo samo jednog odlomka, da tako kažem - zbirnog:

Naime, kao da je cijela javnost sadistički uživala u vrijeđanju svojih bližnjih, pa se nisu propuštale ni najsitnije prilike za otvoreno i bezočno ruganje. Žrtve su morale zatvarati svoje prozore da ne čuju ono što im je neprestance dobacivala ulica, a bilo je i takvih koji su naprosto izbjegavali susrete kako bi bili pošteđeni poruga. Posebnu surovost u tom smislu iskazivala je splitska dječurlija, odnosno mularija [...] (Kudrjavcev 2001: 94)

To bi, otprilike, bio dio istine o legendarnom humoru - umjesto humora tek sadističko iživljavanje nad žrtvama: bolesnima, nemoćnima i drukčijima. Nije, srećom, i sva istina jer su se takvi običaji, čini se, ipak ograničili na ponašanje gradskih besposličara i gradske dekadencije, o čemu svjedoče čuveni i u očima Splićana hvalevrijedni rúčkovi kod velepoštovanog gradonačelnika Vice, dakako jednom godišnje i dakako da bi se ridikuli najeli, ali i napili - i još bolje ih se ismijalo (Vidović 1953). Nema ni zapisa da je institucije ridikula bilo u Dalmatinskoj zagori, istina, možda i zbog "epske" tradicije nesklone smijehu.

Srećom, humora i dobroćudne šale također ima, pa se bez užasavanja nad zlobom i okrutnošću možemo smijati čitajući razne autore, od Držića do Uvodića i Matavulja pa Brešana i Šehovića, a tko god posumnja u to da u Dalmaciji uopće ima humora može pogledati Libar što ga je režirao Vanča Kljaković. ${ }^{20}$ No, to nas ne spašava od drugog dijela istine, od ruganja i ridikula. Zanimljivo je da u Vječnom Splitu još postoji odmak od takve vrste "humora", dok mu se kasnije pripisuje gotovo mitsko obilježje pa se kaže da je "ruganje jedna od najraširenijih i najtipičnijih društvenih navada u mediteranskom svijetu", te se to i takvo okrutno ruganje opravdava time da je "ne imati obzira ni milosti naspram slabijima, glupljima i nakaznijima značilo dokazivati vlastitu moć i vrijednost" (Kudrjavcev 2001: 93). Dapače, a to je doista do mučnine cinično, "onaj kojemu su se rugali zapravo je prekršio pravila simetrije i sklada, bio je, dakle, prekršitelj te je zaslužio porugu" (isto: 95).

Kudrjavcev žali nad tim što, navodno, današnja javnost više ne shvaća i ne prepoznaje prave motive za ruganje. "Današnji javni život naprosto ne prihvaća takve junake, a oni mu se uzaludno nude. Istini za volju, danas ima kudikamo više kandidata za takvu titulu nego ikada ranije, ali javnost ih, eto, neće" (isto). Misli se, naravno, na titulu ridikula, te se sugerira da ih se danas može vidjeti na važnim društveno-političkim nastupima i forumima.

${ }^{20}$ Fenomen Ferala i njegova humora, te njegovo pripadanje ili nepripadanje tradiciji specifično dalmatinskog humora, držimo, zaslužuje poseban osvrt koji smo ovdje prisiljeni ispustiti. 
"Pomozite reći kojima", kaže Kudrjavcev. Tradicija ridikulstva uistinu jest u nestajanju. Na žalost, nije riječ o odmaku od nje, niti o tomu da bi se, umjesto odbačenih, sada ismijavali vladajući. Pretežan bi uzrok njezina izumiranja (ali ne i okrutnosti koja joj se nalazi u temeljima) mogao biti u izmijenjenim okolnostima svakidašnjeg života: teško je zamisliti da bi bilo ikakve, makar i grube "šale" u city centrima, supermarketima u koja se, s Pjace i Rive, premjestilo provođenje čak i slobodnog vremena.

$\mathrm{Na}$ kraju, kako stojimo s odgovorima na početna pitanja o analitičkoj vrijednosti pojma mentalitet, o tomu jesu li eventualne neupitne karakteristike "dalmatinskog mentaliteta" tek predrasude i stereotipovi, odnosno autostereotipovi, a ako jesu, čemu služe, i to ponajprije čemu služe u politici te spadaju li razgovori o dalmatinskom mentalitetu u tipičan orijentalistički, odnosno poluorijentalistički ili čak u posebnu pod/vrstu postkolonijalnog diskursa?

Držimo očitim da za oživljavanje pojma mentaliteta nema baš nikakvih znanstvenih razloga. Čak i u historiografiji, u novoj školi, čuju se glasovi o potrebi strožeg određenja tog pojma. ${ }^{21} \mathrm{Ne}$ događa se ono samo u nas, niti samo u ovdje spomenutim znanostima. Razlozi njegova oživljavanja sasvim su izvanznanstveni, a nalaze se u suvremenom društvu, politici, ekonomiji i u suvremenoj vladajućoj ideologiji te u potrebi okamenjivanja takve politike. Pojam se mentaliteta za te i takve potrebe pokazao upravo idealnim, što smo na nekoliko primjera nastojali i pokazati. Nikakva "samostalnog" značenja, pojam se može "puniti" kojim god značenjem, kome god potrebnim u nekom određenom društvu i prema bilo kojem drugom društvu.

U već spominjanom tekstu "Ideologije i mentaliteti" Michel Vovelle nastoji objasniti kako, obrazovan na marksističkim metodama kojih se ne odriče, ipak pripada povjesničarima mentaliteta (čega se također ne odriče, iako je upravo on jedan od onih smatra da postoji silna potreba za novim generacijama povjesničara mentaliteta koji bi konačno strogo odredili sam pojam mentaliteta), pa priča o marksističkim povjesničarima koji se, nasuprot njemu, bave prije svega ekonomijom i društvenim strukturama i nisu se odlučili za povijest mentaliteta, "ostajući tako zatočeni u podrumu, prepuštajući drugima otmjene katove". Moje je mišljenje da je (opravdani) strah od "vulgarnog" marksizma, međutim, doveo do toga da se na podrum posve zaboravilo. Možda bi ipak valjalo tu i tamo ondje zaviriti pa vidjeti što se uopće u međuvremenu tamo dogodilo? Nema nikakve sumnje da je bilo i da jest i važno i prijeko potrebno iščitavanje "otmjenih katova" koji tako dramatično tresu podnožje, o čemu nam pričaju razne imagološke (od kojih osobito - vezana je

\footnotetext{
${ }^{21}$ Iako ne svuda. Njemačka škola koju predvodi Peter Dinzelbacher za sada im se nije se pridružila. 0 tomu vidi Europäische Mentalitätsgeschichte. 1993. Peter Dinzelbacher (Herausgegeben). Stuttgart: Kröner. Korisnu informaciju o njemačkoj školi nalazimo i kod Zuzane Profantove. Mentality and Historical Memory (dostupno na: https://www.sav.sk/journals/nar/full/sn499d.pdf).
} 
za našu temu - preporučujem onu Joepa Leerseena) ${ }^{22}$ i kulturološke studije, nema sumnje da je bitno govoriti o orijentalizmu, balkanizmu i postkolonijalizmu, kao što nema sumnje ni da je bitno u historiografiju, nasuprot svih napoleona i cezara, sve više uvoditi mennocchije ${ }^{23}$ ovog svijeta, poražene i pobijeđene ljude i ideje.

Bit će, međutim, jednom, potrebno progovoriti i o našem unutrašnjem, minijaturnom, lokalnom orijentalizmu-balkanizmu, onom prema i u Dalmaciji, utječući se za tu priliku više Gramsciju i Todorovoj, nego Saidu (ali to je sasvim nova tema) pa ćemo, valjda, jasnije utvrditi i diskurs i realije. Drugim riječima, što znači, kome i čemu služi kada se za Dalmaciju danas ponavlja ono što je Gramsci pred gotovo stotinu godina uočio kao dominantno prikazivanje talijanskog Juga. “Južnjaci su biološki niža bića, polubarbari ili potpuni barbari, po prirodnoj sudbini; to što je Jug Italije zaostao nije krivnja kapitalističkog sustava ili bilo kojeg drugog povijesnog uzroka, nego prirode koja je južnjake učinila lijenima, nesposobnima, zločincima, barbarima [...]" (Gramsci 1963: 50). Za sada, dok se takvi odgovori ne pojave, "Dalmatinci umiru smijući se". ${ }^{24}$

\section{NAVEDENA LITERATURA I IZVORI}

Ariès, Philippe. 1995. "Povijest mentaliteta”. Gordogan 39-40: 149, 161.

Banac, Ivo. 1992. Dubrovački eseji. Dubrovnik: Matica hrvatska.

Burke, Peter. 1991. Junaci, nitkovi i lude. Zagreb: Školska knjiga.

Čolović, Ivan. 1997. Politika simbola Beograd: Radio B92.

Durkin, Kevin. 2001. "Razvojna socijalna psihologija". U Uvod o socijalnu psihologiju. Miles Hewstone i Wolfgang Stroebe, ur. Jastrebarsko: Naklada Slap.

Eco, Umberto. 1989. Ime ruže. Zagreb: Grafički zavod Hrvatske.

Filipović, Vladimir, ur. 1965. Filozofijski rječnik. Zagreb: Matica hrvatska.

Foucault, Michel. 1980. Istorija ludila u doba klasicizma. Beograd: Nolit.

Freud, Sigmund. 1969. Dosetka i njen odnos prema nesvesnom. Beograd: Matica srpska. Ginzburg, Carlo. 1989. Sir i crvi. Zagreb: Grafički zavod Hrvatske.

\footnotetext{
${ }^{22}$ Joep Leerssen. 2009. “Retorika nacionalnog karaktera: programatski pregled”. U Kako vidimo strane zemlje. Davor Dukić, Zrinka Blažević, Lahorka Plejić Poje i Ivana Brković, ur. Zagreb: Srednja Europa.

23 "U prošlosti su se povjesničari mogli optuživati kako žele upoznati samo 'junačka djela kraljeva'. Danas je, dakako, drukčije. Oni se sve više okreću prema onome što su njihovi prethodnici prešutjeli, odbacili ili jednostavno nisu poznavali. 'Tko je sagradio Tebu sa sedam vrata?' već je pitao Brechtov 'radnički čitatelj'. Izvori nam ništa ne govore o tim nepoznatim zidarima, no pitanje nije nimalo izgubilo na važnosti” (Ginzburg 1989: 7).

${ }^{24}$ U uistinu rijetkoj i jednoj od prvih publikacija iz područja kulturalnih studija o temi Splita i Dalmacije, Split i drugi (uredile Ines Prica i Tea Škokić, IEF i Hrvatsko etnološko društvo, Zagreb 2007.) objavljen je rad Ane Perinić “Galebovi umiru pjevajući”, rad o stereotipovima dalmatinske zabavne ljubavne pjesme. Gorak tekst, gorkog naslova, učinio mi se posve prikladnim parafraziranja.
} 
Gramsci, Antonio. 1963. "Alcuni temi dell questione meridionale". U Antologia degli scritti, 2. Roma: Editori Riuniti.

Hewstone, Miles i Wolfgang Stroebe, ur. 2001. Uvod o socijalnu psihologiju. Jastrebarsko: Naklada Slap.

Kamenov, Željka i Dinka Čorkalo. 1997. "Mjerenje promjena nacionalnih stereotipa. Primjena metode SYMLOG-a”. Društvena istraživanja 2-3: 361-372.

Kaser, Karl. 2007. "Planinski ljudi, ravničarski ljudi. Prostor i etnografska reprezentacija". U Nacija i nacionalizam u hrvatskoj povijesnoj tradiciji. Tomislav Cipek i Josip Vrandečić, ur. Zagreb: Alineja.

Kecmanović, Dušan. 1973. Između normalnog i patološkog. Beograd: Mala edicija Ideja.

Krstulović, Zvonimir. 2001.“Treba osnovati poglavarstvo splitskog spasa!” Slobodna Dalmacija, 23. srpnja 2001.

Kudrjavcev, Anatolij. 1985. Vječni Split. Split: Logos.

Kudrjavcev, Anatolij. 2001. U potrazi za izgubljenim Mediteranom. Split: Knjigotisak.

Kudrjavcev, Anatolij. 2002. Ča je pusta Londra... Split: Marjan tisak.

Jergović, Miljenko. 2003. "Split je grad podijeljen između Thompsona i djece partizana”. Globus, 27. lipnja 2003.

Lacey, A. R. 1996. A Dictionary of Philosophy. London: Routledge.

Le Goff, Jacques. 1998. Civilizacija srednjovjekovnog Zapada. Zagreb: Golden marketing.

Leyens, Jacques-Philippe i Benoit Dardenne. 2001. “Temeljni koncepti i pristupi u području socijalne kognicije". U Uvod o socijalnu psihologiju. Miles Hewstone i Wolfgang Stroebe, ur. Jastrebarsko: Naklada Slap.

Lorger, Mira. 2010. Autonomaši, orjunaši, preporoditelji. Zagreb: VBZ.

Luketić, Katarina. 2013. Balkan. Od geografije do fantazije. Zagreb, Mostar: Algoritam.

Ožegović, Nina. 2001. "Splitski sociolog o desničarskim prosvjedima”. Nacional, 20. veljače 2001.

Paić, Žarko. 2005. Politika identiteta. Zagreb: Antibarbarus.

Pavičić, Jurica. 2004. Split by night. Split, Zagreb: Ex libris.

Petz, Boris, ur. 2005. Psihologijski rječnik. Zagreb: Naklada Slap.

Pilić, Damir i Suzana Kunac. 2003. "Regionalizam. Dalmacija, imat srce lava”. Slobodna Dalmacija, 8. ožujka 2003.

Rihtman-Auguštin, Dunja. 1993. "Dinko Tomašić i hrvatska etnologija/antropologija”. Društvena istraživanja 6/2: 969-973.

Rihtman-Auguštin, Dunja. 1997: “Zašto i otkad se grozimo Balkana?" Erasmus 19: 27-36.

Rihtman-Auguštin, Dunja. 1998: "Politički mit i pozicija etnologa”. Erasmus 23: 72-76.

Rot, Nikola. 1989. Osnovi socijalne psihologije. Beograd: Zavod za udžbenike i nastavna sredstva.

Stančić, Nikša. 1980. Hrvatska nacionalna ideologija preporodnog pokreta u Dalmaciji. Zagreb: Sveučilište u Zagrebu, Centar za povijesne znanosti - Odjel za hrvatsku povijest.

Šidak, Jaroslav, Mirjana Gross, Igor Karaman i Dragovan Šepić. 1968. Povijest hrvatskog naroda g. 1860-1914. Zagreb: Školska knjiga.

Šiber, Ivan. 1998. Osnove političke psihologije. Zagreb: Politička kultura.

Štulhofer, Aleksandar. 1992. "Predviđanje rata? - Etnosociologija Dinka Tomašića”. Društvena istraživanja 2: 299-313. 
Štulhofer, Aleksandar. 1993. "Kako otupjeti Occamovu oštricu". Društvena istraživanja 6/2: 999-1001.

Štulhofer, Aleksandar. 1997. "Dinko A. Tomašić, naš prvi moderni sociolog”. U Dinko A. Tomašić. Politički razvitak Hrvata. Zagreb: Naklada Jesenski i Turk.

Vidović, Radovan. 1953. "Stari Split u humorističkim stihovima Vicka Mihaljevića”. Književni Jadran 2-12: 4-5.

Vovelle, Michel. 1995. "Ideologije i mentaliteti”. Gordogan 39-40.

Vrcan, Srđan. 1999. "Znakovita zbrka oko etničkog”. U Kultura, etničnost, identitet. Jadranka Čačić-Kumpes, ur. Zagreb: Institut za migracije i narodnosti, Naklada Jesenski i Turk, Hrvatsko sociološko društvo, 15-39.

Walters, Minette. 2002. Čegrtuša. Zagreb: Mozaik knjiga.

Zvonarević, Mladen. 1981. Socijalna psihologija. Zagreb: Školska knjiga.

\title{
LAZY, STUPID, TEMPERAMENTAL? THE USE OF STEREOTYPES ABOUT THE DALMATIAN MENTALITY
}

\author{
SUMMARY
}

Lately, all sorts of events taking place in Dalmatia are being explained by an alleged "Dalmatian mentality". This paper is an attempt to answer the questions of what the notion of a mentality should be, whether it has any analytical value or whether it belongs to the obsolete and (justifiably) rejected model of the society, and whether the alleged characteristics of the "Dalmatian mentality" are just prejudices and stereotypes, or autostereotypes, and if they are, what their purpose is - primarily their purpose in daily politics. The paper presents a discussion of whether the Dalmatian mentality discourse belongs to the typical orientalistic/semi-orientalistic, or even a special sort of postcolonial discourse. An attempt is made to show that the reasons of revitalizing the notion of mentality are completely external to science, present in the modern society, modern politics, modern economics and in the modern dominant ideology, aimed at their petrification. Contrary to this, there are numerous reasons which support opening a discussion about our internal, miniature, local orientalismBalcanism, the one towards Dalmatia and in Dalmatia. In doing this, references will be made to Gramsci and Todorova, rather than Said, so as to clearly establish both the discourse and the realia; that is, what it means, who and what it serves when what Gramsci noticed as the dominant presentation of the Italian South almost a hundred years ago is repeated of Dalmatia today.

Keywords: mentality, Dalmatia, stereotypes, buffoons, postcolonialism 